\title{
A Study of Narrative Strategies in A Farewell to Arms
}

\author{
Chen Kaifu ${ }^{1,2}$ \\ ${ }^{1}$ School of Foreign Languages, Leshan Normal University, China \\ ${ }^{2}$ College of Foreign Languages and Literature, Wuhan University, China \\ Correspondence: Chen Kaifu, School of Foreign Languages, Leshan Normal University, Leshan, Sichuan, \\ China.
}

Received: May 13, 2019 Accepted: August 28, 2019 Online Published: August 30, 2019

doi: 10.5539/elt.v12n9p122 URL: https://doi.org/10.5539/elt.v12n9p122

\begin{abstract}
A Farewell to Arms by Ernest Hemingway in his early creative time, has been rated as "the representative classic in the Lost Generation" for its particular narrative strategies. This paper gives a systematic analysis of its narrative order, narrative voice and narrative situation so as to achieve a better interpretation of the narrative effect of this novel.
\end{abstract}

Keywords: A Farewell to Arms, narrative order, narrative voice, narrative situation, narrative strategies

\section{Introduction}

A Farewell to Arms is one of the most influential novels written by Ernest Miller Hemingway. Early in 1918, Ernest Hemingway joined the Italian Red Cross during World War I. On July 8, 1918, while he was on the front lines, a trench mortar shell injured him, so he was sent to a hospital in Milan and there he fell in love with an American nurse named Agnes von Kurowsky in the Red Cross. Hemingway created his such experience into $A$ Farewell to Arms and became the prototype of the protagonist Henry in this novel. It is generally agreed that $A$ Farewell to Arms is a classical anti-war novel vividly depicting the cruel war life, complicated mental world of the servicemen. This novel got an immediate success and won much attention among readers and critics (Beegel, 1996).

\section{Literature Review}

Since its publication, A Farewell to Arms got much attention from scholars at home and abroad. In China, researches mainly focus on analysis of the theme, natural symbolism, characters and translation studies. Wang Zhen (2017) thinks that war and love are the central theme of this novel and Hemingway showed his deep hatred of war. According to the research of this paper, war is the real root of the couple's tragedy in this novel. Some scholars studied the symbols used in A Farewell to Arms. In "Symbolic Uses of the 'Rain' in A Farewell to Arms", Gu Ming, Wang Bo, Yudan (2010) points out that "rain" is an indicator of tragedy and disaster for the couple. In the perspective of characters, Shan Xiaorong (2012) analyzes Catherine Barkley in two sides with examples, putting emphasis on Catherine Barkley's attitudes towards love, war and death, by which the author expresses the cruelness of war and his hatred towards war. Huang Zhuangyong (2017) incisively and vividly depicts the characters' inner feelings and highlights the author's intended theme. In "On Translator's Subjectivity from the Perspective of George Steiner' Hermeneutic Motion Case Study of Two Chinese Translations of $A$ Farewell to Arms", Xu Yuli (2018) stresses the important role of translator's subjectivity based on the comparative study of this novel's two Chinese versions by Lin Yijin and Tang Yongkuan. Wang Kaiqiang (2018) makes a study of the dialogue translation of this novel in "Conversational Implicature as an Approach to Fictional Dialogue Translation: A Case Study of A Farewell to Arms Translated by Lin Yijin", and he finds that the meaning and context are of guiding and evaluating significance to the translation of dialogue in novels.

At abroad, the researchers give more attention to the studies of language features, themes and characters in $A$ Farewell to Arms. Lewis (1992) holds the opinion that the novel's language style was more intriguing than its theme of war. William (1989) stresses impersonal poetics in this novel, and he points that Frederic is actually Hemingway's version of Eliot's poetics of impersonality with its metaphysical mask taken off. Raabe (1999) makes an analysis of anatomical metonymy in A Farewell to Arms. In terms of thematic studies, Gajdusek (1989) analyses the novel from the perspective of integrity psychodynamics and he argues that all relations between individuals are an outcome of life pressures. Some scholars make a study of the characters in this novel. Elliott 
(1993) discusses Henry's crisis of masculinity through an examination of gender fluidity and sexual indeterminacy function. In his essay Whittier (1992) argues that Catherine's death in childbirth has a prophetic significance, which signifies women's procreativity in the interests of male art.

Admittedly, researches on A Farewell to Arms have been making headway at home and abroad. Nevertheless, studies on this novel's narrative approaches have a large room for the further exploration. This paper aims to analyze narrative strategies in A Farewell to Arms, including an analysis of narrative order, narrative voice and narrative situation. It is supposed to promote a better understanding of this novel from the narrative perspective.

\section{Narrative Strategies in $\boldsymbol{A}$ Farewell to Arms}

\subsection{Narrative Order in A Farewell to Arms}

\subsubsection{Chronological Order}

A Farewell to Arms is the one of Hemingway's works written in chronological order.

The plot develops involving around Henry and Catherine. The whole story could be described briefly by the plot of lines: Henry's joining the army, his acquaintance with

Catherine, the love between Henry and Catherine, Henry's departure from the front line and finally Catherine's death in difficult child-birth labor. Hemingway arranged the above series of events by following the time order one after another. The chronological order and cause-and-effect relationship each other make the plot well-knit, coherent and compact.

\subsubsection{Analepsis}

Analepsis is a term put forward by Genette. Traditionally, analepsis is referred as flashback or retrospection. In $A$ Farewell to Arms, Hemingway occasionally takes analepsis. For instance, there is such an episode that Henry withdrew into a barn with his soldiers. While he was lying in the barn, suddenly a sentimental moment came to him:

The hay smelled good and lying in a barn in the hay took away all the years in between. ...... The barn was gone now and one year they had cut the hemlock woods and there were only stumps, dried tree-tops, branches and fireweed where the woods had been. You could not go back. If you did not go forward what happened? You never got back to Milan.

In this analepsis, the protagonist's mind returns to his youth age, which has nothing to do with the previous narrative. Such seemingly irrelevant retrospection presents a contrastive and dramatic effect: the past tranquility and innocent days has gone forever, just despair and violence waiting for them. The employment of analepsis makes the cruelty of war much more prominent and impressive.

\subsubsection{Prolepsis}

According to Genette, prolepsis is a foreshadowing or anticipation in telling a story. In A Farewell to Arms, all the major events are foreshadowed in some way or another, implying the inevitability of the fate. For instance, every time it rains, harmful events will occur to Henry and Catherine. During the summer time, after Henry gets recovery from his leg operation, he intimately talks with Catherine on the veranda of the hospital. At that time, it begins to rain. A chat centering "rain" goes between Henry and Catherine:

"It's raining hard."

"And you will always love me, won't you?"

"Yes." "And the rain won't make any difference?"

"No."

"That's good. Because I am afraid of the rain. I like to walk in it.

But it's very hard on loving. I'm afraid of the rain because sometimes I see me dead in it".

In the dialogue, the rain has a typical symbolic meaning, which foreshadows the gloomy future of their relationship and this is why Catherine feels awesome and burdensome for their love every time it rains. The rain constantly predestines Catherine's fate: finally she dies in the rain.

\subsection{Narrative Voice in A Farewell to Arms}

Narrator's voice, actual voice and implied writer's voice sometimes are mixed, which sometimes is hard to tell. It's a little complicated because voice of narrator is contained by the voice of actual writer and implied writer.

Take the last two sentences of chapter one for an example, "At the start of the winter came the permanent rain 
and with the rain came the cholera. But it was checked and in the end only seven thousand died of it in the army. (6)" It is obviously that Henry does not detect the irony in the word "only". On the contrary, he has responded to another voice - one that can render the ravages of cholera into a statistic about army casualties and that can dismiss the lives of seven thousand soldiers with the word "only". Yet Henry actually is speaking with the voice of the military high command here. Hemingway in this way is presenting Henry not just as a seemingly pure narrator but also a character who does not understand the war or the larger destruction of the world, which also exposes the desolation of the spirit.

In a word, "bi-voice" narration is the prominent feature. It could be found that one voice is Henry-the recorder, speaking from the time of narration; the other is Hemingway - the author. Complicated though it is, narrative voice is a crucial element in a story especially a destruction one.

\subsection{Narrative Situation in A Farewell to Arms}

\subsubsection{Narrative Manner}

Compared to Hemingway's other achievement, it is his mastery of the art of modern narration that makes him win the Nobel Prize. His style puts emphasis on masses of aspects including objectiveness, minimal metaphor, highly selective details, together with neutral and specific choice of diction, amount of use of simple declarative sentences. Hemingway more tends to employ showing instead of telling, and he is adept at transmitting message without any use of the flowery language (Zhang, 2005).

In A Farewell to Arms, Hemingway copes with the accurate observations closely connected with reality so that not only what Frederic sees but also what he feels can help readers get access to the novel. Just as Henry's contemplation in his talk with the clergyman, those abstract terms, such as valiance, honor and glory etc., cannot be applied to the harshness and indifference of the war. Thus speaking of the withdrawal, Hemingway only presents the readers the most concrete and precise details without any romantic and idealistic package of war.

In chapter 15 of the novel, there is a shift away from love and towards to war, another thematic analysis. Hemingway takes a neutral and journalistic style to report the battlefield. In this way it enhances the realism of the narrative and proves incredible unsettling. Indeed, showing is more powerful than telling directly.

Hemingway does not usually attempt to expose his emotion or real inner thoughts of the war. He gives the actions of characters a central place without making any unconnected comments so characters' images are out of natural objects, more illustrative and memorable to readers.

\subsubsection{Narrative Person}

American Lieutenant Frederick Henry is the narrator in A Farewell to Arms. As an ambulance driver, he is the eyewitness of WWI. He lives in the Italian army and met his first final lover----Catherine Barkley. In the third-person point of view, almost everything related to Henry, including his actions, verbal language, and even his inner thoughts are in an unchained position.

Truly, the language in the novel are so brief that he harbors nothing in it, while it successfully makes us struck. When he is at the front, his fear shocked the reader by employing most natural and acceptable words. His love for Catherine, overwhelmed and powerful, make readers emotionally moving. At the end, when Catherine passed by owing to the childbirth, the reader could also feel the heart wrenching. From this point of view, nothing less than narrative person can depict it thoroughly.

Therefore, it is very obvious that Frederick Henry, to some extent, stays true to himself. One time Frederick Henry depicts his living surroundings in detail:

I went out to look at the cars and see what was going on and then came back and sat down in the dugout with the four drivers. We sat on the ground with our backs against the wall and smoked. Outside it was nearly dark. The earth of the dugout was warm and dry and I let my shoulders back against the wall, sitting on the small of my back, and relaxed.

It is a very specific portrayal of Henry's life scene and readers will have a vivid picture on what the ambulance drivers' living conditions. It is still this case when we transfer to Henry's relationship with Catherine. Readers can easily perceive Henry's view of love and the dedicate psychological change from Henry's point of view. Suppose Hemingway took the second or third point of view, it's not likely to demonstrate such valuable experience and real-like life. Actually, one of the novel's attractions is its closeness to readers, and Henry and Catherine are like the common pair of lovers in their life.

From Henry's point of view, it's possible to demonstrate almost every aspect in his life and what is going on between Catherine and himself, including his devotion to Catherine and their baby. The narrator has a god's 
view on the details occurring to them. It's not possible for the readers to get close to their personal life, some of their external behaviors and most of the mental activity if Hemingway takes the other point of view. The dedicate feeling between Henry and Catherine will be easily neglected, and even the general characteristics of this novel may be at the loss or at least quite different.

\section{Conclusion}

There can be little doubt that Hemingway was a great master of narrative arts with a global influence. As the analysis in the above-mentioned, he skillfully employed all the techniques in A Farewell to Arms. This paper gives an exploration of narrative order, narrative voice and narrative situation in this novel, which reflects Hemingway's exceptionally talented writing arts. The tentative probe of the employment of the narrative strategies will give a light on Hemingway's fiction narrative, offering fresh appreciation of Hemingway's works.

\section{References}

Beegel, F. S. (1996). The Critical Reputation of Hemingway. In Scott Donaldson. The Cambridge Companion to Earnest Hemingway. Shanghai: Shanghai Foreign Language Education Press.

Elliott, I. (1993). A Farewell to Arms and Hemingway's Crisis of Masculine Values. Literary Interpretive Theory. https://doi.org/10.1080/10436929308580117

Gajdusek, R. E. (1989). A Farewell to Arms: The Psychodynamics of Integrity. The Hemingway Review.

Gegeruna. (2012). Henry's Tragedy of Disillusionment in Hemingway's A Farewell to Arms. Journal of Language and Literature Studies.

Genette, G. (1980). Narrative Discourse. Trans by Jane F. Lewin. Oxford: Basil Blackwell.

Gu, M., Ma, B., \& Yu, D. (2010). Symbolic Uses of the 'Rain' in A Farewell to Arms. Science \& Technology Information.

Hemingway, Ernest. (2014). A Farewell to Arms. New York: Scribner.

Levis, R. W. (1992). A Farewell to Arms: The War or the Words. New York: Twayne Publishers.

Raabe, D. M. (1999). Hemingway's Anatomical Metonymies. Journal of Modern Literature. https://doi.org/10.1353/jml.1999.0055

Wang, J. (2014). Illness and Lyricism: The Narrative of Women's Trauma in Farewell to Arms. Foreign Literatures.

Wang, K. Q. (2018). Conversational Implicature as an Approach to Fictional Dialogue Translation: A Case Study of $A$ Farewell to Arms Translated by Lin Yijin. Chongqing: Sichuan International Studies University.

Wang, Z. (2017). Death Consciousness and Tragic Narration of War Novels-A Case Study of Farewell to Arms. Journal of Nanyang Institute of Technology.

Whither, G. (1992). Childbirth, War and Creativity in A Farewell to Arms. Literature Interpretation Theory. https://doi.org/10.1080/10436929208580087

William, D. (1989). The Poetics of Impersonality in A Farewell to Arms. University of Toronto Quarterly. https://doi.org/10.3138/utq.59.2.310

Xu, Y. L. (2018). On Translator's Subjectivity from the Perspective of George Steiner' Hermeneutic Motion Case Study of Two Chinese Translations of A Farewell to Arms. Tian Jin: Tianjin University of Commerce.

Zhang, W. (2005). The narrative art of Hemingway's novels. Shanghai: Shanghai Academy of Social Science Press.

\section{Copyrights}

Copyright for this article is retained by the author(s), with first publication rights granted to the journal.

This is an open-access article distributed under the terms and conditions of the Creative Commons Attribution license (http://creativecommons.org/licenses/by/4.0/). 